\title{
CONFORMITY BETWEEN IMMUNIZATION RECORDS IN PRENATAL CHARTS AND VACCINE CONDITIONS OF PREGNANT WOMEN SEEN IN PUBLIC HEALTH SERVICES OF JUNDIAÍ-SP
}

\author{
CONFORMIDADE ENTRE REGISTROS DE IMUNIZAÇÃO EM CARTÕES DE PRÉ- \\ NATAL E A CONDIÇÃO VACINAL DE GESTANTES ATENDIDAS NOS SERVIÇOS \\ PÚBLICOS DE SAÚDE DE JUNDIAÍ-SP
}

\author{
Maria Cristina TRALDI ${ }^{1}$; Camilla Fornezigo TELECK ${ }^{2}$; Juliana Querino TEIXEIRA ${ }^{2}$; \\ Márcia Regina Campos da Costa FONSECA ${ }^{3}$. \\ 1. Professora, Doutora, Faculdade de Medicina de Jundiaí - FMJ, Jundiaí, SP, Brasil. mcristraldi@ gmail.com; 2. Discentes do \\ Curso de Medicina - FMJ, Jundiaí, SP, Brasil; 3. Professora, Doutora, FMJ e da Faculdade São Leopoldo Mandic, Jundiaí, SP, \\ Brasil
}

\begin{abstract}
The records of the vaccine situation in the prenatal charts are an important source of information to be shared among the health teams responsible for maternity assistance. The objective of this study was to evaluate the conformity between the records regarding immunization in the prenatal chart and the information kept in the archives of the Primary Health Center/Family Health Center in which the pregnant woman underwent prenatal care. The 306-woman sample was calculated from the 4017 childbirths that happened in 2013, taking into account the 54\% of pregnant women who were cared for in the Unified Health System (SUS). The inclusion of women in the sample was random and stratified, aiming to work with $15 \%$ of the births performed in each month. The results have shown that only 12.4\% (41/306) of the prenatal charts presented any recorded vaccines; in the health units the record was verified in $49.6 \%(152 / 306)$ of the pregnant women, which meant it was 3.7 times greater in the PHC/FHC. The underreporting of the records increases with the number of pregnant women. Only two types of vaccine were recorded in the charts analyzed: the MMR, in 36 charts $(11.7 \%)$ and the Influenza, in six charts $(1.9 \%)$. In the health units four types were registered, the most frequent of which were the Tetanus: $45.7 \%$ (140/306) and the Hepatitis B: 44.4\% (136/306). The study has shown that there is not a conformity between the information on the vaccination status of the women contained in the prenatal charts and that in the records archived in the health care units where the prenatal assistance was conducted. The situation deserves much more attention on the part of the health professionals who offer assistance to pregnant women, because underreporting of vaccines in prenatal charts reaches more than $80 \%$, and the vaccines of just a little more than half of the pregnant women studied are correctly recorded in the health.
\end{abstract}

KEYWORDS: Women's health. Primary health care. Primary prevention. Health education

\section{INTRODUCTION}

Prenatal care has been substantially increasing in Brazil, positively impacting the maternal and child morbimortality indexes (VICTORA et al., 2011). The access to laboratory tests and to the minimum number of seven consultations during pregnancy has been annually growing (NASCIMENTO, 2003; DOMINGUES, 2012; COUTINHO, 2010). However, the offer and quality of the pregnancy assistance are still a great challenge to the public administration and to health professionals. In 2011, only $64 \%$ of the mothers of children who were born alive in Brazil underwent seven or more prenatal consultations, whereas $10 \%$ of them underwent between zero and three consultations during their pregnancy (DATASUS, 2012).

The challenges that these professionals need to face include the improving of prenatal assistance and of the access to it, and the trustful recording of the actions taken during the monitoring of the pregnant women. There's evidence of the underreporting of such procedures in the prenatal charts, being that immunization is among the most neglected information (SANTOS NETO et al, 2012a; BARRETO; ALBUQUERQUE, 2012; SANTOS NETO et al, 2012b; PARIS et al, 2013; NARCHI et al, 2006; ZANCHI et al, 2013).

The national protocol of prenatal care, defined in the Manual of Low-Risk Prenatal Care, recommends three vaccines in the gestational period, namely: the vaccines against tetanus, hepatitis B (this one introduced in the vaccination schedule in 2011), and most recently, the Influenza Vaccine (BRAZIL, 2002a; BRAZIL, 2013).

The prenatal chart, instituted in 1988 , is an important communication instrument among health professionals who care for pregnant women in different services, throughout their pregnancy, 
during childbirth, and during the puerperium (SANTOS NETO, 2012a). Their main function loses importance when they do not record some essential piece of information, regarding the identification of the pregnant woman, the date of the clinical exams, the type of laboratory test results, as well as the vaccine condition (SANTOS NETO et al, 2012a; BARRETO; ALBUQUERQUE, 2012; SANTOS NETO et al, 2012b; PARIS et al, 2013; ZANCHI et al, 2013).

Thus, the underreporting, on the pregnant woman's chart, of the procedures conducted, means a break in the communication between the different levels of attention and the consequent rupture of the pregnancy history, beyond compromising the health information systems - especially when it comes to the indexes of coverage of the prenatal program.

The information contained in the prenatal chart reveals the course taken by the pregnant woman through the different health services, while the evaluation of the records allows for one to infer on the quality and assistance to the prenatal, preventing the repetition of previously conducted procedures. It also guarantees the control of the process.

One of the limits of studies which evaluate the records of prenatal charts is the impossibility of guaranteeing a connection between the conduction of a test and its presence or absence in a patient's chart (SANTOS NETO et al, 2012a, BARRETO e ALBUQUERQUE, 2012; SANTOS NETO et al, 2012b; PARIS et al, 2012; NARCHI et al, 2006; ZANCHI et al, 2013). The register of vaccines in the prenatal chart is one of the lowest among the several assistance notes conducted during the gestational and puerperium periods.

The objective of this study was to evaluate the conformity between the records regarding vaccines in the prenatal chard and the information contained in the files of the Health Unit where the pregnant woman underwent prenatal exams.

\section{MATERIAL AND METHODS}

This descriptive and sectional study was conducted in the city of Jundiaí-SP, in a public maternity hospital - a SUS (Unified Health System) reference hospital in terms of obstetric assistance and in Basic Health Units/Family Health Units in the public health network of the municipality.

The sample was calculated from the 4017 childbirths that happened in 2013 in the hospital, taking into account the 54\% of pregnant women who live in Jundiaí and have received prenatal care at one of the primary health services in the Unified
Health System (SUS) of the city. The confidence interval of $95 \%$ and the greater possible variety of $50 \%$.

The $15 \%$ proportion of monthly births, adopted as a strategy of stratification in the data collection, has resulted in the sample $n=326$ pregnant women. In order to randomize the sample a list was elaborated, which contained the number of the medical records of the pregnant women cared for each month. After that, the 5th, 10th, 15th and 20th medical records were included, successively. The ones which were not adequate to the inclusion criteria were disposed of, and that process was repeated until the sample of the month was complete.

Pregnant women of all ages were included, but only those who lived in the municipality, underwent their prenatal exams in one of the primary health care services of the city, whose child was born in the hospital where the research was conducted in the year of 2013, and whose records had attached to them a copy of the prenatal chart.

After completing the data collection stage at the hospital, the Primary Health Units/Family Health Units from which each pregnant woman came were identified and included in the sample for the second stage of data collection.

In the comparison of information between the address registered in the hospital records and the register in the PHU/FHU, 20 units of the sample were lost, since the address the indicated was not that of any Primary Unit of the public network, leading to a final result of 306 pregnant women in the sample.

After both stages of the collection, the data was inserted into a Microsoft Excel spreadsheet and submitted to descriptive analysis in order for a sample profile to be obtained. The Pearson test and Yates test were used to assess the dependency level of the interest variables.

The study has observed all the recommendations of the Resolution CNS 466/12 and of the Declaration of Helsinki, and was approved by the Committee of Research Ethics under the protocol number 037969/2014. Since this is a retrospective study, the Free Consent Form was not necessary.

\section{RESULTS}

From the 306 pregnant women studied, only $13.4 \%(41 / 306)$ of the prenatal charts presented any vaccine record; in the primary health units, records were found in $49.6 \%(152 / 306)$, that is, they were 3.7 times more common. 
The average of pregnant women per Primary Health Unit was $8.6 \pm 6.9$, varying from one to 38 women; the average age was $24.8 \pm 6.5$ years old, with a minimum of 13 and a maximum of 42 years old. The higher frequency of age was found in the age group between 20 and 29 years old $(\mathrm{n}=131-42.3 \%) ; 42$ charts did not contain any information regarding age (Table 1).

In the prenatal chard, the space destined to the information regarding marital status presents the following options: married, single, and others; single women were more frequent $(51.6 \%)$ than the other categories, which in this study are brought together in a single one (married and other). The predominant education level was high school, including women with complete or incomplete education.

The results show that a total of $40.2 \%$ $(123 / 306)$ of the women were pregnant for the first time, and these women were those who presented a greatest level of vaccine records in their prenatal charts, when compared with women who had two or more pregnancies. The results show that underreported records increase with the number of pregnancies (Table 1).

The greatest frequency of vaccine records in prenatal charts was found to be among women who were 19 years old or younger, $18.8 \%$ of the total of analyzed records; in the files of the PHU/FHU, however, it was bigger (58\%) among pregnant women who were 30 years old or older. When analyzed regarding marital status, married women present a higher record frequency, both in the charts $(23.9 \%)$ and in the medical records and/or mirrors, in the Health Units (56.3\%) (Table 1).

Only two types of vaccine were recorded in the charts analyzed: the MMR, in 36 charts (11.7\%) and the Influenza, in six charts (1.9\%). In the health units four types were registered, the most frequent of which were the Tetanus: $45.7 \%$ (140/306) and the Hepatitis B: $44.4 \%$ (136/306). The lowest frequency of Influenza vaccine records, 22.2\% (68/264), can be related to the fact that Its application is conducted in specific campaign periods and in some cases, it is registered in a separated chart offered to the pregnant woman.

Table 1. Frequency distribution of vaccine records, according to the source of information, sociodemographic and gestational variables. Jundiaí-SP, 2014.

\begin{tabular}{|c|c|c|c|c|c|c|c|c|c|c|c|c|}
\hline & \multicolumn{6}{|c|}{ Vaccine records in prenatal charts } & \multicolumn{6}{|c|}{ Vaccine records in PHU/FHU } \\
\hline & Total & Yes & & No & & $P$ value & Total & Yes & & No & & $\mathrm{P}$ value \\
\hline & & $\mathrm{n}$ & $\%$ & $\mathrm{n}$ & $\%$ & & & $\mathrm{n}$ & $\%$ & $\mathrm{n}$ & $\%$ & \\
\hline Age group & & & & & & $0.450 *$ & & & & & & $0.454 *$ \\
\hline$\leq 19 \mathrm{y} / \mathrm{o}$ & 64 & 12 & 18.8 & 52 & 81.2 & & 64 & 32 & 50.0 & 32 & 50.0 & \\
\hline $20-29$ & 131 & 16 & 12.2 & 115 & 87.8 & & 131 & 64 & 48.9 & 67 & 51.1 & \\
\hline$\geq 30$ & 69 & 9 & 13.0 & 60 & 87.0 & & 69 & 40 & 58.0 & 29 & 42.0 & \\
\hline $\bar{T}$ Total & 264 & 37 & 14.0 & 227 & 85.9 & & 264 & 136 & 51.5 & 128 & 48.5 & \\
\hline Marital Status & & & & & & $0.025 * *$ & & & & & & $0.456 * *$ \\
\hline Single & 158 & 18 & 11.4 & 140 & 86.6 & & 158 & 79 & 50.0 & 79 & 50.0 & \\
\hline Married & 71 & 17 & 23.9 & 54 & 76.1 & & 71 & 40 & 56.3 & 31 & 43.7 & \\
\hline Total & 229 & 35 & 15.3 & 194 & 84.7 & & 229 & 119 & 52.0 & 110 & 48.0 & \\
\hline Education & & & & & & $0.717 *$ & & & & & & $0.451 *$ \\
\hline Elem. School & 65 & 9 & 13.8 & 56 & 86.2 & & 65 & 31 & 47.7 & 34 & 52.3 & \\
\hline High School & 133 & 19 & 14.3 & 114 & 85.7 & & 133 & 72 & 54.1 & 61 & 45.9 & \\
\hline Higher Education & 19 & 4 & 21.1 & 15 & 78.9 & & 19 & 12 & 63.2 & 7 & 36.8 & \\
\hline Total & 217 & 32 & 14.7 & 185 & 85.3 & & 217 & 115 & 53.0 & 102 & 47.0 & \\
\hline N. Pregnancy & & & & & & $0.156 *$ & & & & & & $0.834 *$ \\
\hline 1 & 123 & 23 & 18.7 & 100 & 81.3 & & 123 & 64 & 52.0 & 59 & 48.0 & \\
\hline 2 & 83 & 11 & 13.3 & 72 & 86.7 & & 83 & 40 & 48.2 & 43 & 51.8 & \\
\hline 3 & 50 & 5 & 10.0 & 45 & 90.0 & & 50 & 28 & 56.0 & 22 & 44.0 & \\
\hline 4 or + & 37 & 2 & 5.4 & 35 & 94.6 & & 37 & 20 & 54.1 & 17 & 45.9 & \\
\hline Total & 293 & 41 & 14.0 & 252 & 86.0 & & 293 & 152 & 51.9 & 141 & 48.1 & \\
\hline
\end{tabular}

* Pearson's Chi-square Test; ** Yates Test

In the association of vaccine records with sociodemographic and pregnancy variables, significant connections were found only to the
MMR vaccine and the variables: education $(\mathrm{p}=0.012)$ and the number of pregnancies $(\mathrm{p}=0.018)$ (Tables 2 and 3). 
Table 2. Frequency distribution of Hepatitis B and MMR vaccines in Health Units, according to the sociodemographic and gestational variables, Jundiaí, SP, 2014.

Records of the Hepatitis B vaccine in

Records of the MMR vaccine in the PHU/FHU PHU/FHU

\begin{tabular}{|c|c|c|c|c|c|c|c|c|c|c|c|c|}
\hline & Total & Yes & & No & & $P$ value & Total & Yes & & No & & $\mathrm{P}$ value \\
\hline & & $\mathrm{N}$ & $\%$ & $\mathrm{n}$ & $\%$ & & & $\mathrm{n}$ & $\%$ & $\mathrm{n}$ & $\%$ & \\
\hline Age group & & & & & & $0.505 *$ & & & & & & $0.201 *$ \\
\hline$\leq 19 \mathrm{y} / \mathrm{o}$ & 64 & 30 & 46.9 & 34 & 53.1 & & 64 & 25 & 39.1 & 39 & 60.9 & \\
\hline $20-29$ & 131 & 57 & 43.5 & 74 & 56.5 & & 131 & 43 & 32.8 & 88 & 67.2 & \\
\hline$\geq 30$ & 69 & 36 & 52.2 & 33 & 47.8 & & 69 & 17 & 24.6 & 54 & 75.4 & \\
\hline Total & 264 & 123 & 46.6 & 141 & 53.4 & & 264 & 85 & 32.2 & 179 & 67.8 & \\
\hline $\begin{array}{l}\text { Marital } \\
\text { Status }\end{array}$ & & & & & & $0.704 * *$ & & & & & & $0.162 * *$ \\
\hline Single & 158 & 72 & 45.6 & 86 & 54.4 & & 158 & 48 & 30.4 & 110 & 69.6 & \\
\hline Married & 71 & 35 & 49.3 & 36 & 50.7 & & 71 & 29 & 40.8 & 42 & 59.2 & \\
\hline Total & 229 & 107 & 46.7 & 122 & 53.3 & & 229 & 77 & 33.6 & 152 & 66.4 & \\
\hline Education & & & & & & $0.508 *$ & & & & & & $0.012 *$ \\
\hline $\begin{array}{l}\text { Elem. } \\
\text { School }\end{array}$ & 65 & 28 & 43.1 & 37 & 56.9 & & 65 & 13 & 20.0 & 52 & 80.0 & \\
\hline $\begin{array}{l}\text { High } \\
\text { School }\end{array}$ & 133 & 64 & 48.1 & 69 & 51.9 & & 133 & 55 & 41.4 & 78 & 58.6 & \\
\hline $\begin{array}{l}\text { Elem. } \\
\text { Education }\end{array}$ & 19 & 11 & 57.9 & 8 & 42.1 & & 19 & 6 & 31.6 & 13 & 68.4 & \\
\hline Total & 217 & 103 & 47.5 & 114 & 52.5 & & 217 & 74 & 34.1 & 143 & 65.9 & \\
\hline $\begin{array}{l}\text { Number of } \\
\text { Pregnancies }\end{array}$ & & & & & & $0.908 *$ & & & & & & $0.018^{*}$ \\
\hline 1 & 123 & 58 & 47.2 & 65 & 52.8 & & 123 & 49 & 39.8 & 74 & 60.2 & \\
\hline 2 & 83 & 37 & 44.6 & 46 & 55.4 & & 83 & 24 & 28.9 & 59 & 71.1 & \\
\hline 3 & 50 & 25 & 50.0 & 25 & 50.0 & & 50 & 19 & 38.0 & 31 & 62.0 & \\
\hline 4 or + & 37 & 16 & 43.2 & 21 & 56.8 & & 37 & 5 & 13.5 & 32 & 86.5 & \\
\hline Total & 293 & 136 & 46.4 & 157 & 53.6 & & 293 & 97 & 33.1 & 196 & 66.9 & \\
\hline
\end{tabular}

Table 3. Frequency distribution of Tetanus and Influenza vaccines in Health Units, according to sociodemographic and gestational variables, Jundiaí, 2014.

\begin{tabular}{|c|c|c|c|c|c|c|c|c|c|c|c|c|}
\hline & \multicolumn{6}{|c|}{ Records of Influenza vaccines in the PHU/FHU } & \multicolumn{6}{|c|}{ Records of Tetanus Vaccines in the PHU/FHU } \\
\hline & Total & Yes & & No & & $\mathrm{P}$ value & Total & Yes & & No & & 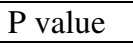 \\
\hline & & $\mathrm{N}$ & $\%$ & $\mathrm{~N}$ & $\%$ & & & $\mathrm{~N}$ & $\%$ & $\mathrm{n}$ & $\%$ & \\
\hline Age group & & & & & & $0.410 *$ & & & & & & $0.521 *$ \\
\hline$\leq 19 \mathrm{y} / \mathrm{o}$ & 64 & 10 & 15.6 & 54 & 84.4 & & 64 & 29 & 45.3 & 35 & 54.7 & \\
\hline $20-29$ & 131 & 31 & 23.7 & 100 & 76.3 & & 131 & 60 & 45.8 & 71 & 54.2 & \\
\hline$\geq 30$ & 69 & 16 & 23.2 & 53 & 76.8 & & 69 & 37 & 53.6 & 32 & 46.4 & \\
\hline Total & 264 & 57 & 21.6 & 207 & 78.4 & & 264 & 126 & 47.7 & 138 & 52.3 & \\
\hline Marital Status & & & & & & $0.626 * *$ & & & & & & $0.428 * *$ \\
\hline Single & 158 & 42 & 26.6 & 116 & 73.4 & & 158 & 74 & 46.8 & 84 & 53.2 & \\
\hline Married & 71 & 16 & 22.5 & 55 & 77.5 & & 71 & 38 & 53.5 & 33 & 46.5 & \\
\hline Total & 229 & 58 & 25.3 & 171 & 74.7 & & 229 & 112 & 48.9 & 117 & 51.1 & \\
\hline Education & & & & & & 0.503 & & & & & & $0.344 *$ \\
\hline Elem. & 65 & 14 & 21.5 & 51 & 78.5 & & 65 & 29 & 44.6 & 36 & 55.4 & \\
\hline High & & 38 & 28.6 & 95 & 71.2 & & 133 & 68 & 51.1 & 65 & 48.9 & \\
\hline Higher Education & 19 & 4 & 21.1 & 15 & 78.9 & & 19 & 12 & 63.2 & 7 & 36.8 & \\
\hline Total & 217 & 56 & 25.8 & 161 & 74.2 & & 217 & 109 & 50.2 & 108 & 49.8 & \\
\hline Number of Pregnancies & & & & & & 0.543 & & & & & & $0.545 *$ \\
\hline 1 & 123 & 24 & 19.5 & 99 & 80.5 & & 123 & 56 & 45.5 & 67 & 54.5 & \\
\hline 2 & 83 & 22 & 26.5 & 61 & 73.5 & & 83 & 37 & 44.6 & 46 & 55.4 & \\
\hline 3 & 50 & 14 & 28.0 & 36 & 72.0 & & 50 & 28 & 56.0 & 22 & 44.0 & \\
\hline 4 or + & 37 & 8 & 21.6 & 29 & 78.4 & & 37 & 19 & 51.4 & 18 & 48.6 & \\
\hline Total & 293 & 68 & 23.2 & 225 & 76.8 & & 293 & 140 & 47.8 & 153 & 52.2 & \\
\hline
\end{tabular}

* Pearson's Chi-square Test; ** Yates Test 


\section{DISCUSSION}

In this study, the vaccine records were low in both the prenatal charts and the researched sources in the Health Units, reaffirming a culture of underreporting health events and procedures that still persists in our country, despite the advance that can be verified after the implantation of electronic systems (SANTOS NETO et al., 2012a; BARRETO, ALBUQUERQUE, 2012; SANTOS NETO et al., 2012; PARIS et al, 2013; NARCHI et al., 2006; ZANCHI et al, 2013; DURÃES OLIVEIRA et al., 2015).

Updated and individualized information are essential to monitor the evolution of the access to and quality of health care, especially of the most vulnerable groups. To this end the countries and supranational organizations such as the Organization for Economic Cooperation and Development (OECD) and the World Health Organization (WHO) have organized discussions on the role of health statistics and the need for reformulation of their bases to better monitor the health of their populations and the performance of their health systems (VIACAVA , 2002).

In order to improve the quality of information about vaccines, the country is implanting the information system of the National Program of Immunizations (SI-PNI) in which the applied dose is individualized by means of personal identification. That will provide accurate information and historical tracking of every individual's vaccination, of vaccination coverage, of the proportion of vaccination scheme abandonment, in addition to the tracking of adverse post-vaccine events (BRAZIL, 2012b; SATO, 2015).

The SI-PNI aims to significantly reduce the underreporting of vaccine records, whose situation is contradictory, considering the high vaccination coverage rates in the country that records levels greater than $70 \%$ for the majority of immunobiologicals in their respective target groups, including the Group of pregnant women (DOMINGUES; TEIXEIRA, 2013).

The objective record of information in the prenatal chart can prevent mistakes, avoid inappropriate and redundant spending and contribute for the pregnant women to receive an adequate assistance. In the specific case of immunization, the record is paramount to ensure the prevention of diseases that can compromise the health of the mother-child dyad (BRAZIL, 2002b; BRAZIL, 2006).

The main aspect of underreporting is the uncertainty regarding the blank spaces in the patients' records that may suggest both the absence of care and the simple lack of registration of the assistance (DOMINGUES, 2012). Both of them, however, compromise the quality of prenatal care, and are indicative of flaws in the care management team responsible for the care of pregnant women, according to the parameters defined in the public policies that defend the reproductive and sexual rights of women, and those of a humanized prenatal care (BRAZIL, 2002a; BRAZIL, 2005).

Another aspect that needs to be highlighted when it comes to information about health is the educational component of the records. Information about the vaccine condition promotes awareness of pregnant women about their right to immunization and the importance of this procedure as a precautionary measure against preventable diseases that can affect the health of both mother and child. Above all, it helps building a favorable attitude regarding self-care and care for the health of the newborn. In Brazil, a study showed that the main reasons for non-adherence to vaccination against rubella was the absence of guidance from the health care professional about its importance $(48.5 \%)$ and ignorance about its necessity (18.9\%) (FRANCISCO et al, 2013).

Among the vaccine-preventable diseases that are important in prenatal care, tetanus is the one with the longest record in public health, as it is part of the PNI and is made available for pregnant women since 1977. Throughout these years of use of the vaccine, the occurrence of accidental tetanus declined sharply, 44\% since 1990, with a coefficient of incidence of $0.17 / 100,000$ inhabitants in 2011 (MILAGRES, 2012).

Accidental tetanus cases occur sporadically throughout the national territory and have a higher incidence in the State of Mato Grosso, which is responsible for $52 \%$ of the cases notified in 2012; from 2007 to 2010, 1238 cases of the disease have been confirmed, its lethality exceeding $30 \%$. Neonatal tetanus (NNT) also became less incident in recent decades, but in 2012, 17 Brazilian States had not yet reached the WHO goal of $<1$ case/thousand live births, since the national incidence is that of 0.13 per 1000 live births (MILAGRES, 2012).

NNT's lethality is elevated, and it can vary from $30 \%$ to $60 \%$ (MILAGRES,2012), or even reach 80\% (OLIVEIRA; NUNES,2013). Efforts must be engaged in order to improve vaccination coverage of women of childbearing age and of prenatal care.

The record of vaccination condition of pregnant women is an indicator of established prenatal processes in the PHPN, and of its collection 
by the Information System on Prenatal (SISPRENATAL). Depending on the source of data collection: SISPRENATAL, (Information System of Children Born Alive (SINASC), or Primary Attention Information System (SIAB), and on the region of the country, the tetanus vaccination coverage of pregnant women ranges from $33.5 \%$ to 89.5\% (MOURA; Rodrigues, 2003; NASCIMENTO et al., 2007; VICTORA et al., 2011).

The tetanus vaccine is the only one recommended in the the Program of Childbirth and Birth Humanization (PHPN), which integrates the indexes of the prenatal process (BRASIL, 2002b, ANDREUCCI; CECATTI, 2011).

From 1993 to 2011 tetanus vaccination coverage (VC) in pregnant women grew throughout the national territory in an inverse proportion of the incidence of NNT. Surveillance must be intensified and PHPN protocols relating to the prevention of TNN followed so that the disease is eradicated. Special attention should be given to the more vulnerable population segments, as people with lower education and socioeconomical conditions are those who less frequently undergo prenatal care and present a lower vaccine coverage (DOMINGUES; TEIXEIRA, 2013). The profile of mothers of babies who received the NNT vaccine in recent years in Brazil indicates that they are women under the age of 25 (66\%), with five or more pregnancies (50\%), illiterate or with up to four years of schooling (66.7\%) and without effective prenatal care, being that $66.7 \%$ report to not have undergone any prenatal consultations (MIRAGRES, 2012).

At the end of 2014 the vaccine absorbed from diphtheria, tetanus and pertussis, the bacterial diphteria-tetanus vaccine for adults, was introduced in the national calendar of vaccination of pregnant women, as a way to strengthen or complement the scheme of the adult double (diphtheria and tetanus) vaccine. The objective of the substitution was to decrease pertussis incidence and mortality rates in newborns, in view of its increasing occurrences in older children, adolescents and adults. The vaccine offers indirect protection in the first months of life due to the transplacental passage of the mother's antibodies to the fetus. This justifies the recommendation that the dyphteria-tetanus vaccine should be made available to pregnant women from their 27th gestational week onwards, up to twenty days before the probable date of childbirth (BRAZIL, 2014).

The MMR vaccine offers protection against measles, mumps and rubella, and it is scheduled in the national children, adolescent, and adult vaccination calendars since 2004. It is not recommended during the gestational period, but it is indicated to susceptible recent mothers, even when breastfeeding. It is $95 \%$ effective. Information on the vaccination status of pregnant women regarding the MMR vaccine in prenatal care is related to risk, especially in the first trimester of pregnancy, of abortion, fetal death, and abnormalities, or congenital rubella syndrome (CRS), serious illnesses that can affect fetuses of mothers who had the acute disease during pregnancy. CRS can provoke from transitory clinical manifestations to permanent ones, such as auditive deficiency, heart malformation, cataract, glaucoma, pigmentary retinopathy, as well as late manifestations, such as development retardation or diabetes mellitus (COSTA et al, 2013).

Until 2001 the confirmed cases of CRS were growing annually, with 107 cases recorded that year. The emphasis on vaccination caused a drop in the statistics. However, in 2006, there was an increase in confirmed cases, and in 2007, the number of notifications reached 8,753, of which 161 occurred in pregnant women, resulting in 29 cases of congenital rubella syndrome in the country. After an intensified vaccination and epidemiological surveillance campaign in 2008 , there was a drop in the number of confirmed cases of rubella $(1,854$ cases), but it was accompanied by an increase in the cases of congenital rubella syndrome, which affected 48 newborns; in 2009 the number fell again, with 15 confirmed cases (FRANCISCO et al, 2013).

The strong association between the MMR vaccine and the educational level $(p=0.012)$ found in this study, suggests a greater knowledge regarding the importance of the specific protection offered by the vaccine against rubella to women with a higher education degree. Among the women in the sample, the majority (133-61.4\%) had completed high school, that is, had completed nine years of elementary school and joined the subsequent cycle. Population segments with a lower cultural level are associated to lower vaccine coverage (MORALES; RIBEIRO, 2008).

Regarding the association between the MMR vaccine and the number of pregnancies, it was found that mothers who were having their first child were more likely to have it in their records, and that the bigger the number of children, the lower the number of records. The smaller amount of records $(13.5 \%)$ was found among women with four or more pregnancies. The significant association between these two variables $(\mathrm{p}=0.018)$, suggests that women with fewer pregnancies are also the youngest, with their MMR vaccines correctly taken 
in childhood or adolescence, and they present their vaccination chart in prenatal consultations contributing favorably to the recording of information in the prenatal chart.

The hepatitis B vaccine was gradually made available in the country, both regarding the geographical aspect and the inclusion of target groups, beginning in the North region of the country in 1989, due to the high endemicity of the disease (prevalence $>7 \%$ ). Adolescents and young adults of up to 20 years old were included in the vaccination schedule of 2004, and later, the groups from 20 to 24 and from 25 to 29 ware included, in 2011 and 2012, respectively (DOMINGUES; TEIXEIRA, 2013).

The hepatitis B vaccination coverage in the country rises as the age of the target group decreases, with $60.7 \%$ variation in the group from 15 to 19 years, to $28.9 \%$ in the Group from 25 to 29 years (DOMINGUES; TEIXEIRA, 2013; BUENO; MATIJASEVICH, 2011).

The serology for hepatitis B (HBsAg) is recommended for all pregnant women, but it is not required in national territory, depending on the availability of the resource. The immunization statement, however, is recommended for all pregnant women who presented negative serology after the first trimester of pregnancy, or in special cases of sexual violence, drug users and other suggestive conditions or suspicion of disease. For positive cases, the vaccine is indicated for the immune globulin, because there is evidence that the schema can avoid $90 \%$ of the vertical transmission of the disease (BRAZIL, 2006; BRAZIL, 2002b; BRAZIL, 2014; BRAZIL, 2009). The adoption of serology in the municipality of origin of the pregnant women sampled might explain why the hepatitis B vaccine was the second most frequent in this study, in terms of records in the health units of the municipality.

The vaccination campaigns against seasonal influenza are carried out since 1999 for people aged 60 years or more. In 2010, in addition to seasonal influenza, vaccination against pandemic influenza A (H1N1), started to be recommended to pregnant women (BRAZIL, 2014). That year, the vaccination coverage of pregnant women did not reach the estimated $80 \%$ target, reaching 77\%. From 2011 on, pregnant women have joined the target groups for vaccination against seasonal influenza and in the same a coverage of $80.9 \%$ was reached (DOMINGUES; TEIXEIRA, 2013).

It should be highlighted that vaccination coverage is calculated using as a basis the estimation of pregnant women in the country. There are no national studies available for comparison of influenza vaccine in the prenatal chart.

Measuring the performance of the processes is one of the main focuses of management within the framework of the basic attention services. The measure subsidizes the establishment of goals and plans actions to achieve them. The record of the procedures performed in maternity care has this objective, regarding the management of prenatal assistance. The elaboration of process indexes depends on the objective and accurate note of activities carried out, because trust is the attribute that guarantees that the data is closely related to the phenomena. When it comes to this, it is relevant to highlight how important it is to update the Prenatal Chart according to the new recommendations of the Ministry of Health, especially when it comes to the immunization of pregnant women. The national model does not accompany the evolution of the PNI, but the prenatal indexes; therefore, it only has a specific space for the register of the Tetanus vaccine. The lack of space does not justify, but it can surreptitiously induce the underreporting of vaccines taken.

\section{CONCLUSIONS}

There is not a conformity between the information on the vaccination status of the women contained in the prenatal charts and that in the records archived in the health care units where the prenatal assistance was conducted.

Vaccine status information is being neglected, and the situation deserves a greater attention on the part of health professionals who offer assistance to pregnant women, because underreporting of vaccines in prenatal cards exceeds $80 \%$, and in health units, it affects half of the pregnant women investigated.

RESUMO: O registro da situação vacinal no cartão de pré-natal é uma importante fonte de informação a ser compartilhada entre as equipes de saúde responsáveis pela assistência da gestante. $\mathrm{O}$ objetivo deste estudo foi avaliar a conformidade entre os registros relativos à imunização no cartão de pré-natal e a informação contida nos arquivos na Unidade Básica de Saúde/Unidade de Saúde da Família na qual a gestante realizou o pré-natal. Amostra de 306 mulheres foi calculada com base nos 4017 partos realizados em 2013, considerando o percentual de $54 \%$ de atendimentos feitos a 
gestantes, usuárias do Sistema Único de Saúde (SUS). A inclusão das mulheres na amostra se deu de forma aleatória e estratificada, buscando-se a proporcionalidade de $15 \%$ dos partos realizados em cada mês. Os resultados mostraram que somente $13,4 \%$ (41/306) dos cartões de pré-natal apresentavam algum registro de vacina; nas unidades de saúde o registro foi verificado em 49,6\% (152/306) das gestantes, sendo 3.7 vezes maior na UBS/USF. A subnotificação do registro aumenta conforme aumenta o número de gestações. Apenas dois tipos de vacinas foram registrados nos CPN analisados: a tríplice viral, em 36 cartões $(11,7 \%)$ e a Influenza, em seis cartões (1,9\%). Nas unidades de saúde foram quatro tipos, sendo mais frequente a Antitetânica: 45,7\% (140/306) e a Hepatite B: 44,4\% (136/306). O estudo mostrou que não há conformidade entre as informações sobre o estado vacinal das gestantes contidas nos cartões de pré-natal e nos registros arquivados nas unidades de saúde onde foi realizada a assistência pré-natal. A situação merece maior atenção por parte dos profissionais de saúde que realizam assistência às gestantes, pois a subnotificação das vacinas nos cartões de pré-natal atinge mais de $80 \%$, e nos registros mantidos nas Unidades de Saúde, pouco mais da metade das gestantes estudadas.

PALAVRAS CHAVE: Saúde da mulher. Atenção Primária. Prevenção primária. Educação em saúde

\section{REFERENCES}

ANDREUCCI, C. B.; CECATTI, J. G. Desempenho de indicadores de processo do Programa de Humanização do Pré-natal e Nascimento no Brasil; uma revisão sistemática. Cadernos de Saúde Pública, Rio de Janeiro, v. 27, n. 6, p. 1053-64, jun. 2011.

BARRETO, F. D. F. P.; ALBUQUERQUE, R. M. Discrepâncias entre o informe verbal e os registros no cartão da gestante, um instrumento negligenciado. Revista Brasileira de Ginecologia e Obstetrícia, Rio de Janeiro, v. 34, n. 6, p. 259-67, jun. 2012.

BRASIL. Ministério da Saúde, Secretaria de Vigilância em Saúde. Informe Técnico sobre Campanha Nacional de Imunização contra a Influenza. Dispõe sobre os critérios para a realização da $\mathbf{1 6}^{\mathbf{a}}$ Campanha Nacional de Vacinação contra a Influenza, no período de 22 de abril a 16 de maio de 2014, sendo 26 de abril, o dia de mobilização nacional. Brasília (DF), 2014.

BRASIL. Ministério da Saúde. Secretaria de Atenção à Saúde. Cadernos de atenção básica: atenção ao prénatal de baixo risco. Brasília: Ministério da Saúde, 2012a.

BRASIL. Ministério da Saúde (BR). Programa de humanização do parto, do pré-natal e nascimento. Brasília (DF): Secretaria Executiva do Ministério da Saúde; 2002b.

BRASIL. Ministério da Saúde. Secretaria de Vigilância e Saúde. Departamento de Vigilância Epidemiológica. Programa Nacional de Imunização, 40 anos. Brasília, Ministério da Saúde; 2013.[internet]Disponível em: $<\mathrm{http}: / /$ www.google.com.br/url?sa=t\&rct=j\&q=\&esrc=s\&source=web\&cd=6\&ved=0CFMQFjAF\&url=http\%3 A\%2F\%2Fbvsms.saude.gov.br\%2Fbvs\%2Fpublicacoes\%2Fprograma_nacional_imunizacoes_pni40.pdf\&ei=t3 VvU9WM5CzsATh7oHIAw\&usg=AFQjCNF5F5sCzyTA2Ko_NTC9ynsRVNabWQ. Acesso: 16 dez 2013.

BRASIL. Ministério da Saúde. Portaria no. 2.363, de 18 de outubro de 2012. Institui repasse financeiro do Fundo Nacional de Saúde aos Fundos de Saúde dos Estados, Distrito Federal e Municípios, por meio do Piso Variável de Vigilância e Promoção da Saúde, para fomento na implantação do Sistema de Informação do Programa Nacional de Imunização (SI-PNI) e Sistema de Informação de Agravos de Notificação (SINAN), no âmbito das unidades de saúde. Diário Oficial da União, Brasília, p.34, 19 outubro 2012b. Seção I.

BRASIL. Ministério da Saúde. Secretaria de Atenção à Saúde. Pré-natal e puerpério, atenção qualificada e humanizada. $3^{\text {a }}$.ed. Brasília (DF); 2006. Série - Direitos Sexuais e Reprodutivos - Caderno no.5. [Manual Técnico].

BRASIL. Ministério da Saúde. Secretaria de Vigilância em Saúde. Nota Técnica No. 39/09/CGPNI/DEVEP/SVS/MS. Nota técnica referente à vacinação de gestantes contra Hepatite B na rede do SUS. Brasília (DF), 08 de setembro de 2009. 
BRASIL. Ministério da Saúde. Informe Técnico para Implantação da Vacina Adsorvida Difteria, Tétano e Coqueluche (Pertussis Acelular) Tipo adulto - dTpa. Brasília (DF): MS/Secretaria de Vigilância em Saúde, 2014.

BUENO, M. M.; MATIJASEVICH, A. Avaliação da cobertura vacinal contra hepatite B nos menores de 20 anos em municípios do Estado do Rio Grande do Sul, Brasil. Epidemiologia e Serviço de Saúde, Brasília, v. 20, n. 3, p. 345-354, mar. 2011. https://doi.org/10.5123/S1679-49742011000300009

COSTA, F. A. S. et al. Síndrome da Rubéola Congênita, revisão da literatura. Revista Medicina e Saúde de Brasília, Brasília, v. 2, n. 1, p. 46ロ57, jan-abr. 2013.

COUTINHO, T. et al. Monitoring the prenatal care process amonh users of the Inified Health Care System in a city of the brasilian South-east. Revista Brasileira de Ginecologia e Obstetrícia. Rio de Janeiro, v.32, n.11, p. 1609-18, nov. 2010.

DATASUS. Indicadores de cobertura. [internet] Disponível em:

<http://tabnet.datasus.gov.br/cgi/tabcgi.exe?idb2012/f06.def>. Acesso em: 08 maio 2014.

DOMINGUES, C. M. A. S.; TEIXEIRA, M. A. S. Coberturas vacinais e doenças imunopreveníveis no Brasil no período 1982-2012, avanços e desafios do Programa Nacional de Imunizações. Epidemiologia e Serviços de Saúde. Brasília, v. 22, n. 1, p. 9-27, abr. 2013.

DOMINGUES I. R. M. S. M. et al. Avaliação da adequação da assistência pré-natal na rede SUS do Município do Rio de Janeiro, Brasil. Cadernos de Saúde Pública.Rio de Janeiro, v. 28, n. 3, p. 425-37, mar. 2012.

DURÃES OLIVEIRA et al. Avaliando a situação vacinal das gestantes nas Estratégias de Saúde da Família de um município. Rede de Cuidados de Saúde [Internet], v. 9, n. 3, p. 1-10, 2015. Disponível em:

<http://publicacoes.unigranrio.br/index.php/rcs/article/view/2537> Acesso em: 12 fev 2016.

FRANCISCO, P. M. S. B. et al. Vacinação contra rubéola em mulheres em idade reprodutiva no município de Campinas, São Paulo, Brasil. Cadernos de Saúde Pública, Rio de Janeiro, v. 29, n. 3, p. 579-88, mar. 2013.

MILAGRES, B. S. Tétanos: Sistema de Vigilância e Cenário Epidemiológico do Brasil e do mundo. Ministério da Saúde: Secretaria de Vigilância em Saúde; 2012. [documento na internet] [aprox. 55 telas]. Disponível em: <www.suvisa.ba.gov.br/./Apresentação_TA\%20e\%20TNN_Oficina_2012_slavador_1(1).pdf> Acesso em: 02 fev 2015.

MORAES, J. C.; RIBEIRO, M. C. S. A. Desigualdades sociais e cobertura vacinal: uso de inquéritos domiciliares. Revista Brasileira de Epidemiologia, Brasília, v. 11, Suppl 1, p. S113-24, 2008. https://doi.org/10.1590/S1415-790X2008000500011

MOURA, E. R. F.; RODRIGUES, M. S. P. Comunicação e informação em saúde no pré-natal. InterfaceComunicação, Saúde Educação, Botucatu, v. 13, n. 13, p. 109-18, ago. 2003.

NARCHI, N. Z. et al. Registro de imunização antitetânica em documentos de mães de uma comunidade carente do município de São Paulo. Online Brasilian Journal Nursing, Niterói, v. 5, n. 2, 2006. Disponível em: <http\|www.objnursing.uff.brqlindex.phpqnursinglrt|printerfriendly1374186> Acesso em: 07 maio 2014.

NASCIMENTO, E. R. et al. Avaliação da cobertura e indicadores do programa de humanização do pré-natal e nascimento em Salvador, Bahia, Brasil. Revista Brasileira de Saúde Materno Infantil. Recife, v. 7, n. 2, p. 191-97, abr-jun. 2007.

NASCIMENTO, L. F. C. Perfil de gestantes atendidas nos períodos pré-natal e puerpério: estudo comparativo entre os serviços público e privado em Guaratinguetá. São Paulo. Revista Brasileira de Saúde Materno e Infantil, Recife, v. 3, p. 187-94, 2003. https://doi.org/10.1590/S1519-38292003000200009 
OLIVEIRA, L. V.; NUNES, C. L. X. Estudo de 119 casos de tétano ocorridos num hospital de referência na Bahia entre 2004 e 2010. Revista Bahiana de Saúde Pública. Salvador, v. 37, Suppl 1, p. 56-67. 2013.

PARIS; G. F. et al. Qualidade da assistência pré-natal nos serviços públicos e privados. Revista Brasileira de Ginecologia e Obstetrícia. Rio de Janeiro, v. 35, n. 10, p. 447-52, out. 2013.

SANTOS NETO, E. T. S. et al (a). O que os cartões de pré-natal das gestantes revelam sobre a assistência nos serviços do SUS da região metropolitana da Grande Vitória, Espírito Santo, Brasil? Cadernos de Saúde Pública. Rio de Janeiro, v. 8, n. 9, p. 1650-1662, set. 2012.

SANTOS NETO, E. T. S. et al.(b) Concordância entre informações do Cartão da Gestante e da memória materna sobre assistência pré-natal. Cadernos de Saúde Pública. Rio de Janeiro, v. 28, n. 2, p. 256-266, fev. 2012.

SATO, A. P. S. Programa Nacional de Imunização: sistema informatizado como opção a novos desafios. Revista Saúde Pública. São Paulo, v. 49, n. 39, aprox.5 p, 2015. Disponível em: < http://www.rsp.fsp.usp.br/mensagem/pub/busca.tpl.php>. Acesso em: 05 mar.2016.

VIACAVA, F. Informações em saúde, a importância dos inquéritos populacionais. Ciência \& Saúde coletiva, Rio de Janeiro, v. 7, n. 4, p. 607-61. 2002. [Debate].

VICTORA, C. G. et al. Maternal and child health in Brazil: progress and challengers. The Lancet, London, v. 377, n. 9780, p. 1863-76, 2011. Disponível em: http://www.thelancet.com/journals/lancet/article/PIIS01406736\%2811\%2960138-4. Acesso em: 05 mar. 2014.

ZANCHI, M. et al. Concordância entre informações do cartão da gestante e o recordatório materno entre puérperas de uma cidade brasileira de médio porte. Cadernos de Saúde Pública. Rio de Janeiro, v. 29, n. 5, p. 1019-28, maio.2013. 